\title{
Spirit Filantropi Islam dalam Tindakan Sosial Rasionalitas Nilai Max Weber
}

\section{Muhammad Erfan}

Magister Ekonomi Syariah, Pascasarjana IAIN Palangka Raya muhammad651@gmail.com

\begin{abstract}
Philanthropy is not limited to loving others related to the economic field, such as zakat, infaq, alms, waqf or others. This study aims to inventory the spirit of Islamic philanthropy in Max Weber's social actions, especially in the act of rationality of values from the behavior of the congregation of Majelis Ratib Atthos Palangka Raya. This study is a qualitative study using data collection techniques in the form of observation and documentation. Data analysis was performed using qualitative procedures. The results of this study found the behavior of the assemblies in the form of social actions of value rationality carried out with the spirit of Islamic philanthropy.
\end{abstract}

Keywords Islamic Philanthropy, Social Action, Value Rationality, Max Weber

\section{PENDAHULUAN}

Menuntut ilmu hukumnya wajib bagi setiap muslim. Tidak terkecuali siapapun, diwajibkan untuk menuntut ilmu sejak buaian hingga ke liang lahad. Bahkan kewajiban menuntut ilmu ditegaskan merupakan kewajiban secara pribadi bagi muslim laki-laki dan muslim perempuan. Di dalam alquran dijelaskan tentang betapa tingginya kedudukan orang-orang yang mempunyai ilmu. Hal ini sebagaimana tercantum dalam alquran surah al-Mujadalah ayat 11: "Wahai orang-orang yang beriman! Apabila dikatakan kepadamu, 'Berilah kelapangan di dalam majelis-majelis,' maka lapangkanlah, niscaya Allah akan memberi kelapangan untukmu. Dan apabila dikatakan, "Berdirilah kamu," maka berdirilah, niscaya Allah akan mengangkat (derajat) orang-orang yang beriman di antaramu dan orang-orang yang diberi ilmu beberapa derajat. Dan Allah Mahateliti apa yang kamu kerjakan."

Dalam rangka melaksanakan kewajiban menuntut ilmu, khususnya ilmu agama, di Kota Palangka Raya banyak sekali majelis-majelis yang digelar oleh berbagai pihak. Di antaranya ada dari pengurus-pengurus masjid, kantor-kantor, lembaga negara atau majelis taklim yang berdiri sendiri, jamaah ibu-ibu dan sebagainya. Majelis-majelis yang didirikan dan digelar tujuannya adalah untuk wadah silaturahmi, belajar dan menambah pengetahuan terutama ilmu agama.

Salah satu bentuk kegiatan belajar yang masuk dalam kategori menuntut ilmu adalah majelis pengajian pembacaan kitab. Di antara sekian banyak majelis pengajian itu salah satunya adalah Majelis Ratib Atthos Palangka Raya. Pada majelis ini disampaikan kajian dari kitab-kitab klasik baik berbahasa Arab maupun Jawi (bahasa Melayu yang ditulis menggunakan aksara Arab). Kitab-kitab ini dibacakan sekaligus disyarahkan oleh seorang ustadz (jamaah lebih suka menyebut dan memanggil beliau dengan sebutan Guru 
dibanding ustadz) yang merupakan salah seorang murid yang pernah beberapa tahun mengikuti pengajian-pengajian pembacaan kitab Syekh Muhammad Zaini bin Abdul Ghani atau yang biasa dikenal dengan sebutan Guru Ijai atau Guru Sekumpul, Martapura, Kalimantan Selatan. Sepengetahuan peneliti, selama mengikuti majelis ini, sudah berlangsung hampir sepuluh tahun. Adapun pengajian yang pernah dan sedang peneliti hadiri secara rutin adalah pengajian yang dilaksanakan setiap malam Senin. Pengajian dilaksanakan dalam rangkaian shalat Magrib berjamaah dilanjutkan kajian kitab Bidayatul Hidayah karya Imam Gazali, pembacaan Ratib Al-Aththas dan shalat Isya berjamaah di masjid al-Azhar komplek Amaco. Selanjutnya pengajian dilanjutkan di markas majelis Jl. Galaksi III No. 12 yang diisi dengan kajian kitab Risalah Ahlussunnah Waljamaah yang disusun oleh Hadratussyaikh Hasyim Asy'ari, namun sebelumnya didahului dengan pembacaan ratib Al-Haddad.

Pada pengajian yang pernah peneliti ikuti, beberapa kajian kitab dibeli sendiri, sedangkan beberapa kajian kitab lainnya dibagikan gratis kepada jamaah yang hadir pada pengajian. Pemberian kitab secara gratis tentunya karena ada jamaah yang menanggung biaya pembelian kitab-kitab tersebut. Sikap-sikap semacam ini, yaitu membantu meringankan biaya jamaah dan memberikan kemudahan dalam menuntut ilmu dan sebagainya, dimiliki oleh beberapa jamaah yang lain bahkan hampir semua jamaah dengan beragam bentuk. Menyediakan makanan atau hanya sekedar air minum juga menjadi sikap yang tampak pada jamaah majelis ini. Sikap filantropis, bersifat filantropi atau berdasarkan cinta kasih terhadap sesama manusia (KBBI versi Daring) yang dilakukan jamaah ini merupakan spirit dan ajaran dari Islam, meskipun istilah filantropi sendiri terdengar seperti baru terutama bagi peneliti.

Namun demikian, secara umum filantropi tidak terbatas pada cinta kasih kepada sesama yang berkaitan dengan bidang ekonomi saja seperti zakat, infak, sedekah, wakaf atau lainnya, tetapi kepada makna kedermawanan yang lebih luas. Sikap cinta, kasih dan sayang kepada sesama berupa materiil maupun non materiil seperti pikiran dan tenaga merupakan tindakan sosial yang patut untuk dilestarikan, terus dipopulerkan, ditularkan dan dijadikan sebagai kebiasaan dalam kehidupan.

Banyak sekali dalil yang menjadi landasan atau konsep dari teori filantropi ini baik dari ayat-ayat alquran maupun hadis-hadis Nabi Muhammad saw. Di antaranya, firman Allah Swt.: "Kamu sekali-kali tidak sampai kepada kebajikan (yang sempurna), sebelum kamu menafkahkan sehahagian harta yang kamu cintai. Dan apa saja yang kamu nafkahkan maka sesungguhnya Allah mengetahuinya." (Q.S. Ali Imran [3]: 92). Sebuah hadis dalam kitab Ibnu Majah hadis nomor 223 atau nomor 227 versi Maktabatu alMa'arif Riyadh, diriwayatkan dari Abu Hurairah, Nabi saw. bersabda: "Barangsiapa mendatangi masjidku ini, ia tidak datang kecuali karena sesuatu yang ia pelajari atau ia ajarkan, maka ia seperti seorang mujahid fi sabillilah. Dan barangsiapa mendatanginya untuk selain itu, maka ia seperti seseorang yang melihat barang milik orang lain." Sedangkan umat Islam diseru berjihad oleh Allah Swt. sebagaimana dalam firman-Nya surat At-Taubah ayat 8: "Tetapi Rasul dan orang-orang yang beriman bersama dia, mereka berjihad dengan harta dan diri mereka. Dan mereka itulah orang-orang yang memperoleh kebaikan, dan mereka itulah orang-orang yang beruntung." Jihad dalam konteks menuntut ilmu selain memerlukan biaya juga memerlukan tenaga dan upaya dalam mencapainya. 
Dalam konteks kelembagaan filantropi di Indonesia, Maryolo (2018) melakukan penelitian yang berfokus pada kelembagaan filantropi, menyimpulkan kehadiran lembaga-lembaga kemanusiaan di Indonesia menandai "praktek baru kedermawanan" gerakan filantropi Islam dalam mewujudkan kesejahteraan publik. Adapun penelitian berkaitan dengan tindakan sosial, Muhlis dan Nurkholis (2016) menulis tentang tindakan sosial Max Weber dalam tradisi pembacaan kitab Mukhtashar Al-Bukhari, menelaah keempat tindakan rasional Max Weber yang tergambar dalam berbagai sikap dalam tradisi pembacaan kitab tersebut. Rahmatia (2019) membuat kajian membandingkan pemikiran Max Weber dan pandangan Islam tentang ekonomi di mana aktivitas ekonomi yang dikritisi oleh kerja dan etika dalam Islam dan meyimpulkan bahwa teori rasionalitas dari Max Weber tidak sejalan dengan pandangan ekonomi Islam sepenuhnya. Adapun peneliti, selama mengikuti pengajian yang dilaksanakan oleh Majelis Ratib Atthos Palangka Raya, banyak dijumpai spirit filantropi dan tindakan-tindakan sosial yang dilakukan oleh jamaah. Sikap, perilaku dan tindakan sosial ini patut untuk diteliti lebih jauh.

Penelitian ini bertujuan untuk menginventarisir spirit filantropi Islam dalam tindakan sosial Max Weber khususnya pada tindakan rasionalitas nilai dari perilaku jamaah Majelis Ratib Atthos Palangka Raya.

\section{LANDASAN TEORI \\ 1. Filantropi Islam}

Filantropi dalam KBBI versi daring berarti "cinta kasih (kedermawanan dan sebagainya) kepada sesama." (Badan Pengembangan Bahasa dan Perbukuan, 2019). Adapun orang yang memiliki sifat filantropi disebut filantropis. Sedangkan menurut istilah yang diperoleh dari ensiklopedia Britannica, filantropi adalah upaya terorganisir secara sukarela yang dimaksudkan untuk tujuan yang berguna secara sosial. Dimulai pada akhir abad ke-19, kekayaan pribadi yang besar mengarah pada pembentukan yayasan swasta yang mewariskan hadiah besar untuk mendukung seni, pendidikan, penelitian medis, kebijakan publik, layanan sosial, program lingkungan, dan tujuan lainnya (Britannica, 2009).

Dalam Islam, filantropi telah ada dan dipraktikkan sejak zaman Nabi Muhammad Saw., yakni sejak 15 abad yang lalu. Dengan landasan teologis dan syariah, praktik filantropi dalam Islam memiliki posisi dan peranan strategis dan menentukan. Islam adalah agama yang sempurna, salah satunya dapat dilihat dari ajarannya yang bersifat komprehensif. Tidak hanya mengatur hubungan manusia dengan Allah Swt. (hablumminallah) saja, tetapi juga mengatur hubungan manusia dengan sesama manusia (hablumminannas), di mana keduanya harus dilakukan secara baik, benar dan seimbang (Amar, 2017). Senada dengan itu Maryolo (2018) menulis bahwa Islam menaruh perhatian yang sangat serius terhadap filantropi. Praktik filantropi telah diatur dalam Islam sebab hal ini merupakan wujud dari hablumminannas. Islam mengajarkan nilainilai kesukarelaan dalam arti kepedulian berbagi dengan orang lain atau menawarkan apa saja kepada mereka yang membutuhkan (Amar, 2017). Adanya kepedulian kepada sesama, perasaan cinta ke sesama manusia, kerelaan tanpa adanya paksaan untuk membantu kepada orang-orang yang membutuhkan, baik berupa materi maupun non materi, merupakan ciri-ciri yang khas dan melekat dalam filantropi. Semua itu dilandasi 
tidak hanya karena kewajiban agama tetapi juga kesadaran akan cinta dan kasih sayang kepada sama manusia (Maryolo, 2018).

Hilman Latif, dalam masyarakat Barat dikenal konsep kedermawanan individu (private charity), aspek ini mempunyai perbedaan secara konseptual dengan kesejahteraan publik (public welfare) yang berada di organisasi atau komunitas. Kegiatan filantropi di dunia Barat dipengaruhi oleh motivasi dan inspirasi keagamaan. Dikatakan bahwa filantropi merupakan konsep universal. Sebagai suatu asas kebaikan, praktik bersedekah, dengan berbagai landasan teologis filosofis dan etis, senantiasa menjadi bagian dari tradisi agama, sebagaimana dikutip oleh Maryolo (2018).

Adapun dalil-dalil tentang konsep dan sikap filantropi sangat banyak dan beragam dengan berbagai bentuknya. Tidak selalu dalam bentuk harta, melainkan juga dalam bentuk yang lain seperti bantuan tenaga dan sebagainya. Beberapa dalil tentang filantropi telah disampaikan peneliti di bagian pendahuluan.

Rois Mahfuz dalam Uyun (2015) menyebutkan bahwa filantropi mengandung hikmah yang sangat banyak. Bagi filantropis, filantropi sebagai mediator dalam meningkatkan iman kepada Allah Swt., menumbuhkan rasa kemanusiaan yang tinggi, menghilangkan sifat kikir, rakus dan materialistis, menumbuhkan ketenangan hidup, membersihkan dan mengembangkan harta yang dimiliki. Sedangkan bagi penerima, filantropi Islam berfungsi untuk menolong, membantu dan membina pada kehidupan yang layak, terhindar dari bahaya kekufuran sekaligus menghilangkan kekufuran, sifat iri dan penyakit hati lainnya.

\section{Tindakan Sosial Max Weber}

Nama lengkap Max Weber adalah Karl Emil Maximillian Weber. Secara bebas kempat kata pembentuk nama Weber itu dapat dipahami demikian: Karl (Jerman, Charles dalam bahasa Inggris, berarti lelaki yang bebas) Emil (dari tradisi Inggris berarti rajin bekerja dan diberkati) Maximillian (berarti 'yang terhebat, terkuat, terbesar') Weber (Jerman, berarti penenun). Weber lahir di Erfrut, Jerman pada Kamis, 21 April 1864, dari keluarga kelas menengah. Kedua orang tuanya memiliki latar belakang dan kecenderungan berbeda, dan itu membentuk karakter pemikiran Weber. Pada usia lima tahun, Weber dan keluarganya pindah dan menetap di Berlin, Jerman. Weber tinggal bersama ayah dan ibunya (Agung, 2016). Dengan semangat bekerja penuh kedisiplinan, akhirnya pada tahun 1896 Weber mencapai status sebagai seorang professor di Heidelberg. Akan tetapi, dibalik keberhasilannya, ayahnya meninggal dunia setelah sempat bertengkar hebat dengannya. Imbas dari apa yang terjadi, Weber mengalami kegamangan dan insomnia. Akibatnya, kesibukan yang sebelumnya berjalan begitu sibuk, mulai longgar terjalankan karena keadaan yang dialaminya. Seiring berjalannya waktu, Weber mulai kembali melanjutkan kegiatan mengajarnya dan menerbitkan sebuah karya yang pada saat itu begitu banyak diperbincangkan dimana-mana yaitu berjudul The Protestant Ethic and The Spirit of Capitalism (Putra, 2020).

Rasionalisasi dalam pengertian Weber yaitu proses meluasnya penggunaan rasionalitas ke dalam segenap aspek kehidupan masyarakat. Yaitu bahwa masyarakat sudah semakin rasional dalam melakukan tindakan-tindakan di berbagai kesempatan dan kegiatan sosial. Tindakan sosial tersebut dilakukan secara bebas dan tanpa paksaan. Artinya dilakukan atas dasar keinginan dirinya sendiri. Karena pengertian yang luas maka rasionalitas Weber menjadi sulit didefinisikan. Sehingga Hastuti, et. al. (2018) dengan 
mengutip G. Ritzer menyebutkan, rasionalitas Max Weber dibedakan menjadi dua jenis yaitu rasionalitas tujuan dan rasionalitas nilai.

Pertama, rasionalitas tujuan (Zwekrationalitaet) adalah rasionalitas yang menyebabkan seseorang atau kelompok orang dalam suatu tindakan berorientasi pada tujuan tindakan, cara mencapainya dan akibatnya. Ciri khasnya adalah bersifat formal, karena hanya mementingkan tujuan dan tidak mengindahkan pertimbangan nilai. Kedua, rasionalitas nilai (Wetrationalitaet) adalah rasionalitas yang mempertimbangkan nilainilai atau norma-norma yang membenarkan atau menyalahkan penggunaan cara tertentu untuk mencapai suatu tujuan. Rasionalitas ini menekankan pada kesadaran nilai-nilai estetis, etis dan religius. Ciri khasnya adalah bersifat substantif, sebab orang yang bertindak ini mementingkan komitmen rasionalitasnya terhadap nilai yang dihayati secara pribadi. Meski terbagi pada dua jenis, rasionalitas pada kenyataannya sering bercampur, terjadi dominasi rasionalitas tujuan atas rasionalitas nilai, demikian sebaliknya.

Selanjutnya atas dasar rasionalitas, Weber membedakan tindakan sosial manusia ke dalam empat tipe. Teori tindakan sosial Max Weber berorientasi pada motif dan tujuan pelaku. Dengan teori ini akan dipahami perilaku setiap individu atau kelompok bahwa masing-masing memiliki motif dan tujuan yang berbeda terhadap sebuah tindakan yang dilakukan (Muhlis \& Nurkholis, 2016). Hasuti et. Al. (2018) merinci tipe-tipe tindakan sosial yang dikemukakan Max Weber yang dimaksud di atas adalah:

a. Tindakan rasionalitas instrumental (zwerk rational);

b. Tindakan rasionalitas nilai (werk rational);

c. Tindakan afektif (affectual action); dan

d. Tindakan tradisional (traditional action).

Pertama, tindakan rasionalitas instrumental, dilakukan atas dasar pertimbangan dan pilihan sadar yang berhubungan dengan tujuan tindakan dan ketersediaan alat yang digunakan untuk mencapainya. Contohnya, ketika diberikan tugas kuliah membuat makalah, maka perlu menggunakan komputer agar tujuan membuat makalah dapat diselesaikan. Kedua, tindakan rasionalitas nilai, dilakukan dengan pertimbangan nilai. Artinya tindakan itu dilakukan mengutamakan apa yang baik, lumrah, wajar atau benar dalam masyarakat pada tujuan individual. Apa yang dianggap baik menurut penilaian masyarakat bisa bersumber dari etika, agama, atau bentuk sumber yang lain. Contohnya, diam ketika orang lain sedang bicara, merendahkan suara ketika mendengar hadis Nabi Muhammad Saw. dibacakan, diam ketika ayat-ayat alquran dibacakan, membungkukkan badan saat lewat di depan orang yang lebih tua, dan sebagainya.

Ketiga, tindakan afektif, tindakan yang dilakukan atas dasar perasaan atau emosi tanpa refleksi intelektual atau perencanaan sadar. Tindakan ini sifatnya tidak rasional, spontan dan merupakan ekspresi emosional dari individu. Contohnya, hubungan kasih sayang dua remaja yang sedang jatuh cinta dan mabuk asmara. Keempat, tindakan tradisional, dilakukan atas dasar kebiasaan yang sudah berakar dan turun-temurun dari nenek moyang tanpa refleksi yang sadar atau dilakukan tanpa perencanaan tujuan tertentu. Misalnya, kebiasaan pulang kampung saat lebaran atau kepercayaan pada mitos "pamali".

\section{METODOLOGI PENELITIAN}

Metode atau pendekatan yang digunakan adalah metode penelitian kualitatif. Penelitian kualitatif merupakan jenis penelitian yang temuan-temuannya tidak diperoleh melalui prosedur statisik atau bentuk hitungan lainnya dan memberikan perincian yang 
lebih kompleks tentang fenomena yang sulit diungkap oleh metode kuantitatif (Abdullah \& Saebani, 2014). Dalam penelitian kualitatif, data yang dikumpulkan merupakan data kualitatif. Bentuk data yang dikumpulkan berupa gambar, kata-kata dan bukannya dalam bentuk angka. Data disajikan dalam bentuk deskriptif atau naratif (Yusuf, 2017). Cara berfikir yang peneliti gunakan adalah cara berfikir deduktif. Lebih lanjut menurut Yusuf (2017), cara berfikir deduktif adalah cara berfikir yang dimulai dengan teori, dan diakhiri dengan fenomena atau hal khusus. Dari pengetahuan yang bersifat umum itu barulah kemudian menilai kejadian-kejadian yang bersifat khusus. Artinya bertolak dari pernyataan yang bersifat umum dan kemudian menarik kesimpulan yang bersifat khusus.

Dalam pengumpulan data, peneliti menggunakan teknik observasi dan dokumentasi. Observasi diartikan sebagai pengamatan terhadap objek penelitian (Tanjung \& Devi, 2013). Teknik observasi digunakan untuk mengetahui atau menyelidiki tingkah laku nonverbal (Yusuf, 2017). Observasi dilakukan dengan mengamati perilaku jamaah pengajian. Sedangkan dokumentasi merupakan catatan atau karya seseorang tentang sesuatu yang telah berlalu. Dalam penelitian kualitatif, dokumen tentang orang atau sekelompok orang, peristiwa atau kejadian dalam situasi sosial yag sesuai dan terkait dengan fokus penelitian adalah sumber yang sangat berguna (Yusuf, 2017). Dokumen dapat berbentuk tulisan, gambar atau karya-karya monumental yang lain (Abdullah \& Saebani, 2014). Dokumen digunakan untuk menerangkan tentang teori-teori Max Weber dan data-data lain terkait dengan bahan-bahan dan atribut pengajian.

Objek penelitian adalah jamaah Majelis Ratib Atthos Palangka Raya, yang markasnya terletak di jalan Galaksi III No. 12 Palangka Raya. Majelis ini juga mengadakan kegiatan pengajian rutin di masjid-masjid pada waktu-waktu yang berbeda di kota Palangka Raya hampir setiap hari yang dilaksanakan setelah shalat Subuh, setelah shalat Magrib dan setelah shalat Isya.

\section{HASIL PENELITIAN DAN PEMBAHASAN \\ 1. Majelis Ratib Atthos Palangka Raya}

Majelis taklim sebagai sebagai salah satu bentuk organisasi dakwah sering juga disebut sebagai pusat pembelajaran Islam, yang diakui telah menyumbangkan peran yang amat besar dalam ikut serta mencerdaskan kehidupan umat dan bangsa, khususnya dalam pengajaran agama dan penguatan moral bangsa. Pada kondisi saat ini, keberadaan majelis taklim dirasakan makin penting dan diharapkan dapat berperan besar dalam menjawab berbagai persoalan yang timbul di masyaarakat. Secara historis, didirikannya majelis taklim dalam masyarakat didasari oleh suatu kesadaran kolektif umat Islam tentang apa betapa pentingnya menuntu ilmu agama dalam kehidupan sehari-hari yang dilakukan secara terorganisir, teratur dan sistemik (Setiawati, 2012).

Majelis Ratib Atthos Palangka Raya adalah salah satu majelis taklim dan sekaligus majelis zikir yang ada di kota Palangka Raya. Nama Majelis Ratib Atthos, diambil dari nama sebuah kumpulan dari bacaan-bacaan zikir tertentu yang disebut ratib disusun oleh Habib Umar bin Abdurrahman Al-Aththas. Badan Pengembangan Bahasa dan Perbukuan (2019) dalam KBBI Daring mengartikan ratib dengan puji-pujian atau doa kepada Tuhan yang diucapkanberulang-ulang, seperti La ilaha illallah, Allahu akbar; zikir. Setiap pelaksanaan pengajian, di majelis ini selalu dibacakan Ratib Al-Aththas secara bersamasama dipimpin oleh Guru atau khadimul majelis. Dilihat secara keorganisasian, majelis ini tidak memiliki pengurus maupun struktur kepemimpinan. Tetapi ada beberapa jamaah 
yang mendedikasikan diri untuk mengurusi majelis ini secara sukarela. Namun dalam berbagai praktiknya, segala sesuatu yang akan dilakukan untuk kepentingan majelis, selalu ditanyakan atau dibicarakan terlebih dahulu kepada Guru atau khadimul majelis untuk meminta pendapat dan persetujuan beliau.

Peneliti memperhatikan selama mengikuti kegiatan majelis ini baik di markas maupun di beberapa masjid, hampir selalu ada tiga orang yang selalu duduk di hadapan Guru. Mereka mendokumentasikan kajian-kajian majelis ini secara sukarela untuk membantu keberlangsungan majelis, misalnya dengan menayangkan pengajian secara live di media sosial. Kemudian merekam dan membagikan hasil remakan kepada jamaah. Beberapa orang lagi mendedikasikan diri untuk menyediakan minum bagi Guru. Jamaah lain ada pula yang membuatkan website untuk kepentingan majelis. Peneliti menemukan ada dua alamat website majelis yaitu https://ratibatthos.blogspot.com dan https://www.ratibatthos.com. Majelis ini juga memiliki beberapa Whatsapp Group yang digunakan untuk membagikan dokumentasi rekaman pengajian saat majelis serta informasi lainnya secara searah kepada jamaah.

\section{Spirit Filantropi Islam dalam Tindakan Rasionalitas Nilai}

Pengajian yang diselenggarakan Majelis Ratib Atthos Palangka Raya dihadiri oleh jamaah yang jumlahnya cukup banyak, berasal dari berbagai kalangan. Berdasarkan pengamatan peneliti, tidak hanya kalangan pelajar atau santri tetapi juga ada dari kalangan dosen, mahasiswa, aparatur pemerintah dan swasta. Kalangan terbanyak yang mengikuti pengajian memang pedagang. Mayoritas dari jamaah ini adalah masyarakat suku Banjar meski banyak pula yang berasal dari suku lain seperti Bakumpai, Jawa dan lain-lain. Umumnya semua suku menempatkan orang-orang khusus seperti Guru pada posisi yang dimuliakan dan dihormati. Terkadang pengajian juga dihadiri oleh tokoh atau guru-guru lain bahkan para Habaib.

Banyaknya jamaah yang mengikuti pengajian ini menimbulkan adanya beraneka ragam tindakan-tindakan sosial yang mereka lakukan terhadap Guru. Terlebih lagi corak dan bentuk pengajian mirip dengan model pengajian yang dilaksanakan oleh Guru Ijai. Sehingga memunculkan karisma tersendiri pada diri Guru yang membacakan dan mensyarahkan kitab-kitab dalam pengajian di majelis ini. Peneliti mengikuti pengajian ini sekaligus mengamati dan turut mengamalkan beberapa tindakan-tindakan yang dilakukan oleh jamaah kepada Guru. Peneliti melihat adanya nuansa, spirit, dan esensi dari filantropi Islam di dalam berbagai tindakan sosial jamaah khususnya tindakan sosial rasionalitas nilai, baik kepada Guru maupun kepada jamaah lain. Tentu alasan utama tindakan sosial rasionalitas nilai itu mereka dasarkan pada landasan teologis dan syariah.

Berikut peneliti uraikan spirit filantropi Islam dengan makna yang luas dalam tindakan-tindakan sosial berbasis rasionalitas nilai Max Weber dari jamaah Majelis Ratib Atthos Palangka Raya yang tampak dalam observasi peneliti:

1. Beberapa jamaah berinisiatif untuk membeli dan membagikan kitab yang dibahas pada dalam pengajian kepada jamaah lain yang hadir pada saat pertemuan awal pembacaan kitab. Ini dilakukan dengan maksud agar tercapai kemudahan dalam menuntut ilmu, dapat sama-sama melihat langsung teks kitab, bukan hanya mendengarkan saja. Diharapkan dengan adanya kitab yang dimiliki masing-masing jamaah dapat mempemudah dan mempercepat kepahaman terhadap materi yang sedang disampaikan oleh Guru. Filantropi sedekah kitab ini menurut peneliti masuk 
dalam rangkaian pengamalan hadis tentang terputusnya amal anak cucu Adam kecuali tiga hal, salah duanya adalah amal jariyah dan ilmu yang bermanfaat.

2. Jamaah sengaja menunggu Guru datang, kemudian membawakan tas dan meletakkannya di atas meja untuk mengajar. Demikian pula saat Guru akan meninggalkan majelis, jamaah berinisiatif mengambilkan tas dan menyerahkannya kepada Guru. Sedekah tenaga menjadi salah satu cabang filantropi yang diamalkan beberapa jamaah, hingga terkadang beradu cepat dengan jamaah lain untuk melakukannya. Sebagian lain bersedakah tenaga dengan cara menyiapkan kendaraan Guru agar berada di posisi siap digunakan ketika Guru keluar dari tempat pangajian. Peneliti berbaik sangka kepada ikhwan jamaah majelis bahwa selain karena adab mereka kepada Guru, juga karena mengamalkan sunah Nabi Muhammad saw. "Sebaik-baik manusia adalah yang paling bermanfaat bagi orang lain." Diriwayatkan oleh Ibnu Hibban dari Jabir bin Abdullah. Ada pula riwayat dari Imam At-Thabrani dalam Al-Mu'jam Al-Awsath dari Jabi bin abdullah dengan redaksi yang berbeda. Hadis ini dinilai beragam oleh para ahli hadis, ada rawi yang diragukan, tetapi Al-Albani menyebutkan hadis ini termasuk hadis hasan.

3. Sangat jelas peneliti lihat saat pengajian berlangsung, beberapa jamaah yang diberikan air minum mineral gelas lebih mementingkan jamaah lain untuk diberikan air minum. Bahkan mereka mempersilakan jamaah di sebelahnya untuk minum sedangkan dia sendiri tidak mendapatkan air minum. Sangat mungkin jamaah ini sedang mengamalkan hadis Nabi saw. bahwa sedekah terbaik adalah memberikan air minum. Imam An-Nasa'i meriwayatkan dari Sa'd bin 'Ubadah, hadis nomor 3605 atau nomor 3665 menurut versi Maktabatu al-Ma'arif Riyadh dengan derajat hasan, “Aku bertanya, 'Wahai Rasulullah, sedekah apakah yang paling utama?' Beliau menjawab: 'Memberi minum air." Demikian pula dalam hadis yang terkenal, tentang seorang pelacur yang mengambilkan air menggunakan sepatunya lalu memberikan air tersebut untuk minum kepada seekor anjing yang hampir mati kehausan, sebagaimana diriwayatkan oleh Abu Hurairah yang diriwayatkan oleh Muslim nomor hadis 4163 atau nomor 2245 pada versi Syarh Shahih Muslim dengan derajat hadis sahih.

4. Salah seorang jamaah menyediakan tempat berupa sebuah rumah untuk dijadikan sebagai markas majelis. Rumah ini terletak di jalan Galaksi III no. 12 yang sekarang sudah difungsikan sebagai markas dan digunakan pula untuk kegiatan pengajian. Tindakan ini benar-benar melaksanakan firman Allah Swt. dalam surah Ali Imran ayat 92 yang sudah disampaikan sebelumnya. Terlepas dari yang bersangkutan memiliki beberapa atau kekayaan yang berlimpah, sikap filantropi ini tentu didasarkan pada keyakinan akan kebenaran firman Allah Swt. Dengan menyediakan rumah sebagai markas sangat membantu jamaah untuk menuntut ilmu agama.

5. Proses rehab dan rekondisi rumah yang dijadikan markas, di beberapa bagian rumah dibantu sepenuhnya oleh jamaah lainnya. Termasuk bahan bangunan dan pekerja yang mengerjakan rehab langsung dilaksanakan oleh jamaah. Peneliti melihat sikapsikap ini sebagai bentuk kecintaan kepada ilmu, rasa hormat kepada Guru dan semangat untuk membantu penyebaran ilmu agama kepada masyarakat luas. Sikap filantropi yang berakar pada sifat kedermawanan jamaah ini menjadi kemudahan bagi jamaah lain. 
6. Beberapa orang relawan mendedikasikan diri untuk mendokumentasikan dan membagikan hasil dokumentasi kepada jamaah lain. Jamaah lain membuatkan website untuk publikasi dokumentasi pengajian. Membantu dalam memudahkan penyampaian ilmu kepada orang lain adalah wujud filantropi Islam yang berdasar kuat pada nas. Dalam kitab hadis Abu Daud nomor 3173 atau nomor hadis 3658 pada versi Baitul Afkar Ad-Dauliah, diriwayatkan dari sahabat Abu Hurairah dengan derajat hadis hasan sahih, Rasulullah bersabda: "Barangsiapa ditanya mengenai suatu ilmu dan ia menyembunyikannya, maka ia akan dicambuk dengan cambuk dari api neraka pada hari kiamat." Sedangkan pahala besar bagi orang yang mengajak dan menyampaikan kebaikan kepada orang, sebagaimana hadis sahih riwayat Muslim nomor 4831 atau nomor 2674 versi Syarh Shahih Muslim, dari Abu Hurairah. Bahwa Nabi saw. bersabda: "Barang siapa mengajak kepada kebaikan, maka ia akan mendapat pahala sebanyak pahala yang diperoleh orang-orang yang mengikutinya tanpa mengurangi pahala mereka sedikitpun. Sebaliknya, barang siapa mengajak kepada kesesatan, maka ia akan mendapat dosa sebanyak yang diperoleh orangorang yang mengikutinya tanpa mengurangi dosa mereka sedikitpun." Jika dipandang dari sisi ekonomi, sikap filantropi relawan tersebut adalah sebuah investasi akhirat di samping kebaikan dan manfaat bagi jamaah lain.

7. Saat pengajian terutama yang dilaksanakan di markas majelis, selalu ada yang membawa atau mengantarkan makanan, baik karena hajat tertentu atau sekedar bersedakah makan saja kepada jamaah. Pengamalan konsep filantropi tentang perbuatan terbaik dalam Islam, sebagaimana jawaban Nabi saw. atas pernyataan sahabat, yaitu memberi makan kepada orang lain. Dalam sebuah hadis qudsi yang cukup panjang bahkan Allah Swt. bertanya kepada anak Adam: "Wahai anak Adam, Aku meminta makan kepadamu namun kamu tidak memberi makan kepada-Ku. Kemudian anak Adam bertanya: "Wahai Tuhanku, bagaimana aku memberi makan kepadamu, sedangkan Engkau adalah Rabb alam semesta?" Allah berfirman: "Tidakkah kamu mengetahui bahwasanya hamba-Ku si Fulan minta makan kepadamu, tetapi kamu tidak memberi makan kepadanya? Apakah kamu tidak mengetahui bahwasanya seandainya kamu memberi makan kepadanya, niscaya kamu mendapatkan ia di sisi-Ku?"

8. Ketika proses distribusi makanan, banyak jamaah yang ikut membantu dengan tenaganya untuk mengedarkan dan membagikan makanan kepada jamaah lain. Pada saat itu peneliti menyaksikan di antara sesama jamaah tampak mendahulukan jamaah lain untuk mendapatkan makanan lebih dahulu dibandingkan dirinya.

\section{KESIMPULAN}

Spirit filantropi Islam tampak pada berbagai macam perilaku jamaah Majelis Ratib Atthos Palangka Raya yang tercermin dalam tindakan-tindakan sosial rasionalitas nilai Max Weber. Kedermawanan berupa pemberian bantuan dalam bentuk apapun, baik materi maupun non materi dilakukan oleh jamaah untuk Guru dan jamaah lain didasarkan pada spirit filantropi Islam. Spirit filantropi Islam ini menjadikan tindakan-tindakan yang dilakukan oleh jamaah memiliki nilai rasional dan bersesuaian secara estetis, etis dan relijius. 
Kajian ini cukup terbatas karena peneliti hanya melakukan penelitian pada satu tindakan sosial saja dari empat tindakan sosial rasional yang dikemukan oleh Max Weber, sehingga terbuka kesempatan bagi peneliti lain untuk mengembangkan kajian ini lebih lanjut.

\section{DAFTAR PUSTAKA}

Abdullah, B., \& Saebani, B. A. (2014). Metode Penelitian Ekonomi Islam (Muamalah). Bandung: CV. Pustaka Setia.

Agung, M. N. (2016). Weber: "Nabi” Etika Protestan, Bapak Verstehen. PAX HUMANA, 3(1), 057-066.

Amar, F. (2017). Implementasi Filantropi Islam Di Indonesia. Al-Urban: Jurnal Ekonomi Syariah Dan Filantropi Islam, 1 (1), 1-14.

Badan Pengembangan Bahasa dan Perbukuan. (2019). KBBI Daring (versi 2.0.1.020191010103941). https://kbbi.kemdikbud.go.id/, diakses 6 Oktober 2020.

Britannica. (2009). Philanthropy: Definition, History, \& Facts. https://www.britannica.com/topic/philanthropy, diakses 6 Oktober 2020.

Hastuti et. al. (2018). Pendekatan Perspektif Weber terhadap Tindakan Rasionalisme Pembuatan Perahu Pinisi. Indonesian Journal of Fundamental Sciences, 4 (2), 147155.

Maryolo, A. (2018). Filantropi Berbasis Faith Based Organization di Indonesia (Studi Kasus Program PKPU). Palita: Journal of Social Religion Research, 2 (1), 13-2424.

Muhlis, A., \& Norkholis. (2016). Analisis Tindakan Sosial Max Weber dalam Tradisi Pembacaan Kitab Mukhtasar Al-Bukhari (Studi Living Hadis). Jurnal Living Hadis, 1 (2), 242-258.

Putra, A. (2020). Konsep Agama dalam Perspektif Max Weber. Al-Adyan: Journal of Religious Studies, 1 (1), 39-51.

Rahmatia, A. (2019). A Study of Max Weber Thought on Its Relation to Work Purposes and Ethics in The Islamic Economics. JURNAL TRANSFORMATIF (ISLAMIC STUDIES), 3 (1), 19-41.

Setiawati, N. (2012). Majelis Taklim Dan Tantangan Pengembangan Dakwah. Jurnal Dakwah Tabligh, 13 (1), 81-95.

Sudrajat, A. (1992). Tesis Weber Dan Islam Di Indonesia. Jurnal Cakrawala Pendidikan, $1(1)$.

Tanjung, H., \& Devi, A. (2013). Metodologi Penelitian Ekonomi Islam. Bekasi: Gramata Publishing.

Uyun, Q. (2015). Zakat, Infaq, Shadaqah, dan Wakaf Sebagai Konfigurasi Filantropi Islam. Islamuna: Jurnal Studi Islam, 2 (2), 218-234. 


\section{JESY^}

JURNAL EKONOMI \& EKONOMI SYARIAH

Jurnal Ekonomi \& Ekonomi Syariah Vol 4 No 1, Januari 2021

E-ISSN : 2599-3410 | P-ISSN : 2614-3259

DOI : https://doi.org/10.36778/jesya.v4i1.281

Yusuf, M. (2017). Metode Penelitian Kuantitatif, Kualitatif dan Penelitian Gabungan. Jakarta: Kencana. 